\title{
Occurrence of anti-Brucella abortus agglutinins in small ruminants in Sergipe
}

\author{
Ocorrência de aglutininas anti-Brucella abortus \\ em pequenos ruminantes de Sergipe
}

\begin{abstract}
Huber Rizzo ${ }^{1 *}$ (D), Rachel Livingstone Felizola Soares de Andrade ${ }^{2}$ (D), Helen Carolina de Oliveira Menezes ${ }^{2}$ (D), Urias Fagner Santos Nascimento ${ }^{2}$ (D), Ícaro Wille dos Santos Silva ${ }^{3}$ (D), Taile Katiele Sousa de Jesus ${ }^{2}$ (D), Jeferson Silva Carvalho' ${ }^{(D)}$ Lília Márcia Paulin Silva ${ }^{4}$
\end{abstract}

\begin{abstract}
The objective this study was to evaluate the occurrence of small ruminants seropositive for Brucella abortus in Sergipe, Brazil. Samples of sheep $(1,200)$ and goats (675) serum blood was collected from 101 farms of 25 counties of the three mesoregions of the state. The technique of Acidified Buffered Acid stained with Rose Bengal (RB) was used and all samples confirmed a positive result using the 2-Mercaptoethanol technique. Four $(0.21 \%)$ seropositive animals were diagnosed by technique AAT stained with RB, three sheep's $(0.25 \%)$ and a goat $(0.15 \%)$, were confirmed by the $2 \mathrm{ME}$ test. In all the positive properties, the intercropping of small ruminants with cattle was adopted, favoring the contact with the agent. The prevalence of anti-B. abortus antibodies in herds of small ruminants in Sergipe is described for the first time, and is low, however, it is important to identify seropositive animals to be discarded due to their zoonotic potential.
\end{abstract}

KEYWORDS: buffered acidified antigen; brucellosis; ovine; caprine; serology.
RESUMO: Objetivou-se avaliar a ocorrência de pequenos ruminantes soropositivos para Brucella abortus em Sergipe, Brasil, a partir de 1.200 amostras de soro sanguíneo de ovinos e 675 de caprinos, oriundos de 101 propriedades de 25 municípios das três mesorregiôes do estado, nas quais foi empregada a técnica do Antígeno Acidificado Tamponado (AAT) corado com Rosa Bengala (RB) como triagem e do 2-Mercaptoetanol (2ME) como confirmatória. Foram diagnosticados 4 animais $(0,21 \%)$ soropositivos pela técnica de AAT corado com RB, 3 ovelhas $(0,25 \%)$ e 1 cabra $(0,15 \%)$, que posteriormente foram confirmados pelo teste de $2 \mathrm{ME}$. Em todas as propriedades positivas era adotada a criaçáo consorciada de pequenos ruminantes com bovinos, favorecendo o contato com o agente causador. A ocorrência de anticorpos anti-B. abortus em rebanhos sergipanos de pequenos ruminantes é descrita pela primeira vez, e mostra-se baixa; entretanto, é importante a identificaçáo de animais soropositivos para que sejam descartados, devido seu potencial zoonótico.

PALAVRAS-CHAVE: antígeno acidificado tamponado; brucelose; ovinos; caprinos; sorologia.

\footnotetext{
'Universidade Federal Rural de Pernambuco - Recife (PE), Brazil

${ }^{2}$ Faculdade Pio Décimo, Câmpus III - Aracaju (SE), Brazil

${ }^{3}$ Universidade Federal de Sergipe - São Cristovam (SE), Brazil

${ }^{4}$ Instituto Biológico - São Paulo (SP), Brazil

*Corresponding author: hubervet@gmail.com

Received on: 02/26/2019. Accepted on: 08/26/2019
} 
Brucellosis is an infecto-contagious and zoonotic disease of importance in the ruminants breeding, caused by Brucella abortus in cattle, B. ovis in sheep, and B. melitensis in goats. It may also occur sporadic infection among these species (MANISH et al., 2013), mainly by $B$. abortus in small ruminants in the intercropped breeding with cattle, where transmission occurs through digestive tract from contact with secretions and miscarriages and/or through the supply of milk from seropositive cows to neonates (CARNEIRO et al., 2005; VARGES et al., 2008). Infected animals may present reproductive disorders such as abortion, placental retention, epididymitis, and orchitis, becoming also potential transmitters of the disease to man (MANISH et al., 2013).

Although microbiological isolation is the most effective method for diagnosing the disease, indirect serological methods are the most routinely used, since they offer high sensitivity and low cost when recommended for cattle and buffaloes. However, it should not be adopted alone mainly in programs of control and eradication of the disease (KALTUNGO et al., 2014), being those recommended by the National Program for the Control and Eradication of Brucellosis Tuberculosis (PNCEBT) the test of the buffered acidified antigen (AAT), 2-mercaptoethanol (2-ME) and the complement fixation reaction (RFC) (MEIRELLES-BARTOLI; MATHIAS, 2010).

Given the scarcity of data about this disease in Sergipe, this study aimed to report the occurrence of $B$. abortus agglutinins in goats and sheep bred in the state.

During the years 2011 and 2014, in 25 municipalities of Sergipe, according to the availability of producers, 101 properties of small ruminants distributed in the three mesoregions of the state were visited: East $(n=44)$, Agreste $(n=30)$, and Sertão $(\mathrm{n}=27)$. Of these, 1,875 samples $(1,556$ females and 319 males) were collected by venopunction of the external jugular, being 1,200 of sheep, between the years of 2011 and 2012, and 675 of goats, between 2013 and 2014, of 60 and 41 properties respectively, where randomly selected and without repetition, from seven to twenty animals of different zootechnical patterns, apparently healthy, aged over six months and with no history of vaccination for brucellosis. The biological material was processed in the serology laboratory of the Faculdade Pio Décimo, Aracaju, Sergipe, and the blood serum was subjected to research of anti- $B$ abortus agglutinins by the technique of AAT stained with RB, prepared and commercialized by the Biological Institute of São Paulo. Samples that contained formation of clumps of agglutination were considered positive. Subsequently, the positive sera by the technique of AAT stained with RB were submitted to the 2-ME method for confirmation (MADRUGA et al., 2001). Descriptive statistical analysis by absolute and relative distribution was used to calculate the occurrence. The research project was approved by the Ethics committee of the Faculdade Pio Décimo, Aracaju, Sergipe, under the number 06/2011 of April 16, 2011.

Of the 1,875 serum from small ruminants created in Sergipe, submitted to anti- $B$ abortus agglutinin research by the technique of AAT stained with RB, 4 (0.21\%) females were seropositive, 3 ewes of Santa Inês breed, $0.25 \%$ of sheep, and 1 goat without definite breed, $0.15 \%$ of goats (Table 1 ). The serum of these four animals when tested by the 2-ME test confirmed the seropositivity, thus reducing the chances of false positive animals, since it is more specific than the AAT stained with RB, however less sensitive, besides identifying vaccinal antibodies. There is the possibility of performing the RFC, as a confirmatory serological test, especially in cases of positive animals for the AAT stained with RB and inconclusive for the $2 \mathrm{ME}$, due to its high specificity (MEIRELLES-BARTOLI; MATHIAS, 2010; KALTUNGO et al., 2014), a situation that did not occur with sera from the positive sheep and goats of Sergipe.

Even with low occurrence, small infected ruminants were identified, which may serve as disseminators of the disease in herds, not observed in surveys carried out in Minas Gerais (SALABERRY et al., 2011), Paraná (PASQUALI et al., 2017) and in northeastern herds of the semiarid of Paraiba (ALVES et al., 1997), Sertáo de Itaparica, Pernambuco (NASCIMENTO et al., 2015), Teresina, Piauí (DA SILVA et al., 2017), Petrolina in Pernambuco, and Juazeiro and Valente (PEIXOTO et al., 2016) and region of Senhor do Bonfim, Bahia (ALBUQUERQUE et al., 2014), with no seropositive animals among those surveyed. Studies that identified small seropositive ruminants found rates between 0.2 and $9 \%$ in the states of Rio de Janeiro (FRAGUAS et al., 2004; LILENBAUM et al., 2007; VARGES et al., 2008), Mato Grosso (SANTOS et al., 2016), Pernambuco (PINHEIRO JUNIOR et al., 2008), and Tocantins (MARTINS et al., 2013).

In $3.33 \%(2 / 60)$ and $2.44 \%(1 / 41)$ of the properties of sheep and goats, at least one seropositive animal was diagnosed, where they all adopted the breeding intercropped with cattle, which was observed in $85 \%$ (51/60) and $41.5 \%$ (17/41) of the breeding of sheep and goats studied. This association between dairy goats and cattle was reported in studies that presented high seropositive rates in relation to the other national studies in Bahia (CARNEIRO et al., 2005) and Rio de Janeiro where the cow that provided milk for the goats was diagnosed infected by $B$. abortus (VARGES et al., 2008) and the herds that had seropositive caprine animals had a history of lactation with bovine milk (LILENBAUM et al., 2007). In sheep, the presence of bovine animals was also reported by SANTOS et al. (2016), in Mato Grosso, which attempted to compromise the PNCEBT in the state due to the presence of infected sheep in cattle herds, in addition to the risk of public health (CARNEIRO et al., 2005). The 3 properties with seropositive animals presented occurrence of $10 \%(1 / 20)$ and $20 \%(2 / 20)$, and were located in different municipalities (Simão Dias, Estancia, and Salgado), representing $12 \%(3 / 25)$ of the surveyed. In relation to the Mesoregions, in the Sertão $(n=504)$ all animals were seronegative, while in the Agreste and East were diagnosed two animals each, representing $0.39 \%(2 / 513)$ and $0.23 \%$ (2/858) of the small ruminants collected in the respective mesoregions. None of the seropositives was created in the extensive system, predominantly observed in 
the Sertão mesoregion, which has a drier climate in relation to the others, reducing the availability of Brucellas in the environment (MANISH et al., 2013). According to CARNEIRO et al. (2005), there is a relationship between the breeding system and the seropositivity, being the animals under semi-intensive regime more predisposed to contract the disease in relation to the intensive. Sanitary conditions, climate, and breeding system can contribute to the differences observed in the various regions surveyed (CARNEIRO et al., 2005; PINHEIRO JUNIOR et al., 2008).

The presence of antibodies anti-B. abortus in Sergipe herds of small ruminants was very low. However, it is important to identify seropositive animals to be discarded, especially in properties with breeding with cattle due to the predilection of $B$. abortus to this species of ruminants and their zoonotic potential.

\section{ACKNOWLEDGMENT}

To the Scientific Initiation and Extension Group in Buiatria of the Faculdade Pio Décimo, Aracaju, Sergipe, for the execution of the project.

Table 1. Occurrence of antibodies anti-B. abortus in serum from small ruminants determined by AAT and 2-ME, according to properties with seropositive animals, municipalities, and mesoregion of the state of Sergipe. 2011-2014.

\begin{tabular}{|c|c|c|c|c|c|c|}
\hline \multirow[b]{2}{*}{ Municipality } & \multicolumn{2}{|c|}{ Goats (\%) } & \multicolumn{2}{|c|}{ Sheep } & \multicolumn{2}{|c|}{ Total } \\
\hline & $\begin{array}{l}\text { Prop. (+)/ } \\
\text { Prop. }\end{array}$ & Positive/Total & $\begin{array}{l}\text { Prop. (+)/ } \\
\text { Prop. }\end{array}$ & Positive/Total & $\begin{array}{c}\text { Prop. (+)/ } \\
\text { Prop. }\end{array}$ & Positive/Total \\
\hline Aracaju & $0 / 3(0)$ & $0 / 50(0)$ & $0 / 1(0)$ & $0 / 20(0)$ & $0 / 4(0)$ & $0 / 70(0)$ \\
\hline Arauá & - & - & $0 / 3(0)$ & $0 / 60(0)$ & $0 / 3(0)$ & $0 / 60(0)$ \\
\hline Boquim & - & - & $0 / 1(0)$ & $0 / 20(0)$ & $0 / 1(0)$ & $0 / 20(0)$ \\
\hline Divina Pastora & - & - & $0 / 3(0)$ & $0 / 60(0)$ & $0 / 3(0)$ & $0 / 60(0)$ \\
\hline Estância & $0 / 1(0)$ & $0 / 20(0)$ & $1 / 4(25)$ & $1 / 80(1,25)$ & $1 / 5(20)$ & $1 / 100(1)$ \\
\hline Itabaianinha & - & - & $0 / 9(0)$ & $0 / 180(0)$ & $0 / 9(0)$ & $0 / 180(0)$ \\
\hline Itaporanga D’Ajuda & $0 / 1(0)$ & $0 / 20(0)$ & $0 / 5(0)$ & $0 / 100(0)$ & $0 / 6(0)$ & $0 / 120(0)$ \\
\hline Maruim & - & - & $0 / 2(0)$ & $0 / 40(0)$ & $0 / 2(0)$ & $0 / 40(0)$ \\
\hline Nossa Sra. do Socorro & $0 / 1(0)$ & $0 / 18(0)$ & $0 / 1(0)$ & $0 / 20(0)$ & $0 / 2(0)$ & $0 / 38(0)$ \\
\hline Salgado & $1 / 2(50)$ & $0 / 30(0)$ & $0 / 3(0)$ & $0 / 60(0)$ & $1 / 5(20)$ & $1 / 90(1,1)$ \\
\hline São Cristóvão & $0 / 1(0)$ & $0 / 20(0)$ & $0 / 2(0)$ & $0 / 40(0)$ & $0 / 3(0)$ & $0 / 60(0)$ \\
\hline Neópolis & $0 / 1(0)$ & $0 / 20(0)$ & - & - & $0 / 1(0)$ & $0 / 20(0)$ \\
\hline Mesorregião Leste & $1 / 10(10)$ & $1 / 178(0,56)$ & $1 / 34(2,94)$ & $1 / 680(0,15)$ & $2 / 44(4,55)$ & $2 / 858(0,23)$ \\
\hline Cumbe & - & - & $0 / 1(0)$ & $0 / 20(0)$ & $0 / 1(0)$ & $0 / 20(0)$ \\
\hline Itabaiana & $0 / 1(0)$ & $0 / 20(0)$ & - & - & $0 / 1(0)$ & $0 / 20(0)$ \\
\hline Lagarto & $0 / 1(0)$ & $0 / 19(0)$ & $0 / 6(0)$ & $0 / 120(0)$ & $0 / 7(0)$ & $0 / 139(0)$ \\
\hline Macambira & $0 / 3(0)$ & $0 / 42(0)$ & - & - & $0 / 3(0)$ & $0 / 42(0)$ \\
\hline Nossa Sra. das Dores & - & - & $0 / 4(0)$ & $0 / 80(0)$ & $0 / 4(0)$ & $0 / 80(0)$ \\
\hline Poço Verde & $0 / 11(0)$ & $0 / 154(0)$ & - & - & $0 / 11(0)$ & $0 / 154(0)$ \\
\hline Simão Dias & - & - & $2 / 3(66,7)$ & $2 / 60(3,33)$ & $2 / 3(66,7)$ & $2 / 60(3,33)$ \\
\hline Mesorregião Agreste & $0 / 16(0)$ & $0 / 235(0)$ & $2 / 14(14,29)$ & $2 / 280(0,71)$ & $2 / 30(6,67)$ & $2 / 515(0,39)$ \\
\hline Canindé São Francisco & $0 / 6(0)$ & $0 / 119(0)$ & $0 / 4(0)$ & $0 / 80(0)$ & $0 / 10(0)$ & $0 / 199(0)$ \\
\hline Feira Nova & - & - & $0 / 2(0)$ & $0 / 40(0)$ & $0 / 2(0)$ & $0 / 40(0)$ \\
\hline Itabi & - & - & $0 / 2(0)$ & $0 / 80(0)$ & $0 / 2(0)$ & $0 / 80(0)$ \\
\hline Nossa Sra. da Glória & $0 / 6(0)$ & $0 / 93(0)$ & $0 / 4(0)$ & $0 / 80(0)$ & $0 / 10(0)$ & $0 / 173(0)$ \\
\hline Pedra Mole & $0 / 1(0)$ & $0 / 11(0)$ & - & - & $0 / 1(0)$ & $0 / 11(0)$ \\
\hline Pinhão & $0 / 2(0)$ & $0 / 39(0)$ & - & - & $0 / 2(0)$ & $0 / 39(0)$ \\
\hline Mesorregião Sertão & $0 / 15(0)$ & $80 / 262(0)$ & $0 / 12(0)$ & $0 / 280(0)$ & $0 / 27(0)$ & $0 / 542(0)$ \\
\hline Total & $1 / 41(2,44)$ & $1 / 675(0,15)$ & $3 / 60(5)$ & $3 / 1.200(0,25)$ & $4 / 101(3,96)$ & $4 / 1.875(0,21)$ \\
\hline
\end{tabular}

Prop. (+): properties with at least one seropositive animal for $B$. abortus.

Prop.: total properties that were performed to collect serum for diagnosis of $B$. abortus 

REFERENCES

ALBUQUERQUE, I.R.R.; GOIS, G.C.; CAMPOS, F.S. Perfil sanitário de cabras lactantes da região de Senhor do Bonfim, Bahia. Acta Veterinaria Brasilica, Mossoró, v.8, n.82, p.144-149, 2014. Available from: <https://www.researchgate.net/ publication/283090097_PERFIL_SANITARIO_DE_CABRAS_ LACTANTES_DA_REGIAO_DE_SENHOR_DO_BONFIM_BAHIA_ Profile_goat_herd_health_in_senhor_of_bonfim_Bahia>. Access on: 14 Feb. 2019.

ALVES, C.J.; VASCONCELLOS, S.A.; MORAIS, Z.A.; LEITE, E.A.; GOMES, A.A.B. Avaliação dos níveis de aglutininas anti-Brucella em soros de caprinos de cinco centros de criação do nordeste do Brasil. Revista Brasileira de Ciência Veterinária, Seropédica, v.4, n.3, p.89-91, 1997. Available from: <http://periodicos.uff.br/ rbcv/article/view/7419>. Access on: 14 Feb. 2019.

CARNEIRO, J; ZACHARIAS, F; PACHECO, ST; MENDONÇALIMA, FW. Investigação da soropositividade para brucelose em rebanhos caprinos produtores de leite para consumo humano. Revista Brasileira de Saúde e Produção Animal, Salvador, v.6, n.2, p.53-58, 2005. Available from: <https://repositorio.ufba. $\mathrm{br} / \mathrm{ri} / \mathrm{bitstream} / \mathrm{ri} / 1882 / 1 / 631-2445-2-\mathrm{PB} . \mathrm{pdf}>$. Access on: 13 Feb. 2019.

DA SILVA, G.A.; LEITE, A.G.P.M.; TEIXEIRA, L.S.A.; ARAÚJO, E.K.D.; DAS VIRGENS, M.S.; VIEIRA, R.J.; MINEIRO, A.L.B.B. Inquérito soro-epidemiológico de Brucella ovis e Brucella abortus em rebanhos ovinos pertencentes à microrregião de Teresina, Brasil. Pubvet, Maringá, v.1 1, n.5, p.470-475, 2017. Available from: <http://www.pubvet.com.br/pesquisa?palavra=brucelose $>$. Access on: 14 Feb. 2019.

FRÁGUAS, S.A.; RISTOW, P.; CARDOSO, V.S.; SOUZA, G.N.; LILENBAUM, W. Ocorrência de brucelose caprina em propriedades de exploração leiteira do estado do Rio de Janeiro. Revista Brasileira de Medicina Veterinária, Rio de Janeiro, v.26, n.1, p.21-25, 2004. Available from: <https://www.dropbox.com/s/ nj6unpp9mqrigrO/2004\%20-\%200corr\%C3\%AAncia\%20 de\%20brucelose\%20caprina\%20em\%20propriedades\%20 de\%20explora\%C3\%A7\%C3\%A30\%20leiteira\%20do\%20 Estado\%20do\%2ORio\%2Ode\%20Janeiro.pdf?dl=01 >. Access on: 14 Feb. 2019.

KALTUNGO, B.Y.; SAIDU, S.N.A.; SACKEY, A.K.B.; KAZEEM, H.M. A review on diagnostic techniques for brucellosis. African Journal of Biotechnology, Nairobi, v.13, n.1, p.1-10, 2014. Available from: <https://www.ajol.info/index.php/ajb/article/ viewFile/ 1 16688/106268>. Access on: 21 Jun. 2019. https:// doi.org/10.5897/AJB2013.13442

LILENBAUM, W.; SOUZA, G.N.; RISTOW, P.; MOREIRA, M.C.; FRÁGUAS, S.; CARDOSO, V.S.; OELEMANN, W.M.R. A serological study on Brucella abortus, caprine arthritis-encephalitis virus and Leptospira in dairy goats in Rio de Janeiro, Brazil. The Veterinary Journal, London, v.173, n.2, p.408-412, 2007. Available from: <https://www.sciencedirect.com/science/article/ pii/S1090023305003047?via\%3Dihub>. Access on: 18 jun. 2019. https://doi.org/10.1016/j.tvjl.2005.12.003
MADRUGA, C.R.; DE ARAÚJO, F.R.; SOARES, C.O. Imunodiagnóstico em Medicina Veterinária. Campo Grande: Embrapa, 2001. 360p.

MANISH, K; PURAN, C; RAJESH, C; TEENA, R; SUNIL, K. Brucellosis: an updated review of the disease. Indian Journal of Animal Sciences, New Delhi, v.83, n. 1, p.3-16, 2013. Available from: <https://www.researchgate.net/publication/285958312_ Brucellosis_An_updated_review_of_the_disease $>$. Access on: 14 Feb. 2019.

MARTINS, N.E.X.; ALMEIDA, J.D.M.; SILVA, M.G.; SOUSA, M.G.; MATHIAS, L.A.; ALMEIDA, K.S. Prevalência de anticorpos antiBrucella ovis e anti-Brucella abortus em ovinos do município de colinas, Tocantins, Brasil. Revista de Patologia Tropical, Goiânia, v.42, n.2, p.147-160, 2013. Available from: <https://www. revistas.ufg.br/iptsp/article/view/25525>. Access on: 14 Feb. 2019. https://doi.org/10.5216/rpt.v42i2.25525

MEIRELLES-BARTOLI, R.B.; MATHIAS, L.A. Estudo comparativo entre os testes adotados pelo PNCEBT para o diagnóstico sorológico da brucelose em bovinos. Arquivos do Instituto Biológico, São Paulo, v.77, n.1, p.11-17, 2010. Available from: <http:// www.biologico.sp.gov.br/uploads/docs/arq/v77_1/meirelles. pdf>. Access on: 18 Jun. 2019.

NASCIMENTO, M.F.; FERRAZ, M.L.; DA SILVA, F.S.; DE SOUZA, E.Z.; SÁ, M.S.; COSTA, M.M.; PEIXOTO, R.M. Sororreatividade para Brucella abortus e Brucella ovis em pequenos ruminantes no Sertão de Itaparica, PE. Revista Semiárido De Visu, Petrolina, v.3, n.3, p.111-117, 2015. Available from: <https://periodicos. ifsertao-pe.edu.br/ojs2/index.php/revista/ article/view/123>. Access on: 14 Feb. 2019.

PASQUALI, A.K.S.; CHIDEROLI, R.T.; BENITEZ, A.N.; CALDART, E.T.; EVERS, F.; FORTES, M.S.; FERREIRA, F.P.; MONTEIRO, K.C.; GIORDANO, L.G.P.; FREIRE, R.L.; FREITAS, J.C.; NAVARRO, I.T. Cross-sectional study of Leptospira spp. and Brucela abortus in goat herds from Paraná State, Brazil. Acta Scientiae Veterinariae, Porto Alegre, v.45, n. 1, p. 1444, 2017. Available from: <https:// seer.ufrgs.br/ActaScientiaeVeterinariae/article/view/79794>. Access on: 12 Feb. 2019.

PEIXOTO, R.M.; SANTOS, G.B.; AMANSO, E.S.; SÁ, M.C.A.; ARAÚJO, R.M.P.; COSTA, M.M. Anti-lentivirus, Brucella abortus and $B$. ovis antibodies in small ruminants raised in Pernambuco and Bahia. Revista Caatinga, Mossoró, v.29, n.2, p.507-51 1, 2016. Available from: <http://www.scielo.br/scielo.php?script=sci_ arttext\&pid=S1983-21252016000200507>. Access on: 14 Feb. 2019.

PINHEIRO JUNIOR, J.W.; SOUZA, M.M.A.; GUERRA, N.R.; SANTANA, V.L.A.; MOTA, RA. Frequência de Aglutininas anti-Brucella ovis em caprinos e ovinos do Sertão do Estado de Pernambuco. Ciência Animal Brasileira, Goiás, v.9, n.4, p.1096-1101, 2008. Available from: <https://www.revistas.ufg.br/vet/article/view/1379>. Access on: 14 Feb. 2019. 
SALABERRY, S.R.S.; PAULIN, L.M.; SANTANA, R.L.; CASTRO, J.R.; LIMA-RIBEIRO, A.M.C. Pesquisa de anticorpos anti-Brucella abortus e anti-Brucella ovis em ovinos no município de Uberlândia, MG. Arquivo Brasileiro de Medicina Veterinária e Zootecnia, Belo Horizonte, v.63, n.4, p.1022-1024, 2011. Available from: <http://www.scielo.br/pdf/abmvz/v63n4/32.pdf>. Access on: 14 Feb. 2019.

SANTOS, R.; SOUZA, A.A.D.; GOMES, S.C.; SOCOLOSKI, S.N.G.; CASTRO, B.G. Pesquisa de anticorpos anti-Brucella abortus em ovinos da região Médio-Norte Matogrossense. Veterinária e
Zootecnia, Botucatu, v.23, n.4, p.642-646, 2016. Available from: <https://www.bvs-vet.org.br/vetindex/periodicos/veterinaria-ezootecnia/23-(2016)-4/pesquisa-de-anticorpos-anti-brucellaabortus-em-ovinos-da-regiao-medio/> . Access on: 14 Feb. 2019.

VARGES, R; MEDEIROS, L; LILENBAUM, W. Sororreatividade para Brucella abortus em rebanho caprino no estado do Rio de Janeiro, Brasil: relato de caso. Revista Brasileira de Ciência Veterinária, Seropédica, v.15, n.2, p.103-104, 2008. Available from: <http://doi.editoracubo.com.br/10.4322/rbcv.2014.204>. Access on: 14 Feb. 2019 